MaPan : Jurnal Matematika dan Pembelajaran

p-ISSN: 2354-6883 ; e-ISSN: 2581-172X

Volume 8, No 2, Dec 2020 (329-342)

DOI: https://doi.org/10.24252/mapan.2020v8n2a11

\title{
ALGEBRAIC THINKING ABILITY AND LEARNING INTEREST THROUGH SOCIAL MEDIA-BASED PICTORIAL PUZZLE IN NEW NORMAL ERA
}

\author{
Putik Rustika1), Titi Rohaeti2) \\ 1,2 Universitas Muhammadiyah Cirebon \\ 1,2 Jl. Fatahilah Watubelah Sumber No. 40 \\ Email: putikrustika@gmail.com¹), titirohaeti@umc.ac.id2)
}

Received October 24, 2020; Revised November 30, 2020; Accepted December 31, 2020

\begin{abstract}
Algebraic ability is one of the most important abilities to be developed because it becomes the basis to achieve other mathematical thinking ability. In new normal era, information through social media is the main thing for society, particularly for children of the current generation. This study aims to describe algebraic thinking ability and students' interest in learning through social media-based pictorial puzzles. The method of the research is descriptive quantitative. The samples of this study were 6 students of grade VIII SMP Edu Global School in Cirebon city. This study indicates that algebraic thinking ability and students' interest in learning algebra are still classified as moderate and have not reached the high category, so it needs to be improved in the learning process.
\end{abstract}

Keywords: Algebraic Thinking, Learning Interest, Picture Puzzle

\section{KEMAMPUAN BERPIKIR ALJABAR DAN MINAT BELAJAR MELALUI TEKA-TEKI KARTUN BERGAMBAR BERBASIS SOSIAL MEDIA DI ERA NEW NORMAL}

\begin{abstract}
Abstrak
Kemampuan aljabar merupakan salah satu kemampuan yang sangat penting dikembangkan karena menjadi dasar untuk mencapai kemampuan berpikir matematis lainnya. Pada era new normal, informasi melalui sosial media menjadi hal yang utama bagi masyarakat terutama untuk anak-anak generasi sekarang. Penelitian ini bertujuan untuk mendeskripsikan kemampuan berpikir aljabar dan minat belajar siswa melalui teka-teki kartun bergambar berbasis sosial media. Metode yang digunakan adalah kuantitatif deskriptif. Sampel penelitian ini adalah 6 siswa SMP kelas 8 di Edu Global School di kota Cirebon. Hasil dari penelitian ini menyatakan kemampuan berpikir aljabar dan minat belajar siswa terhadap aljabar masih tergolong sedang, belum mencapai kategori tinggi, sehingga sangat perlu ditingkatkan lagi dalam proses pembelajarannya.
\end{abstract}

Kata Kunci: Berpikir Aljabar, Minat Belajar, Teka-Teki Bergambar 
How to Cite: Rustika, P. \& Rohaet, T. (2020). Algebraic Thinking Ability and Learning Interest Through Social Media-Based Pictorial Puzzle in New Normal Era. MaPan : $\begin{array}{llll}\text { Jurnal Matematika dan } & \text { 8(2), 329-342. }\end{array}$ https://doi.org/10.24252/mapan.2020v8n2a11.

\section{INTRODUCTION}

$\mathrm{M}$

athematics is one of the most important fields of science in the real of education. Wanti, Juariah, Farlina, Kariadinata, and Sugilar (2017) defines mathematics as a process of reasoning and the formation of thought patterns that can be used to make conclusions. A person's ability to reason and think logically is a characteristic of mathematics. BSNP (2006) in Putri, Sulianto, and Azizah (2019) also reveals that mathematics equips students with logical thinking skills. Gardner explains that logical-mathematical intelligence consists of studying problems, solving logical and analytical problems, performing mathematical operations, and carrying out scientific investigations (Maftoon \& Sarem, 2012). Another ability in mathematics is the ability to think algebraically. This is the main ability in learning mathematics before going to the advanced stage of mathematical thinking. The ability to think algebra for children is usually introduced early on and what is usually introduced is to count the number of objects with different categories. As stated by Vance in Angriani (2017) algebra is sometimes defined as a generalization of arithmetic, but the emphasis on algebra is much broader than just a set of rules for manipulating symbols, namely, algebra is a way of thinking. Along with physical development, a person's ability to reason abstractly also increases, so that the ability to count also increases, not only recognizing the number of numbers but also can perform numerical counting operations such as adding, subtracting, multiplying, and dividing in algebraic content.

Algebra material is material that is the basis for understanding higher mathematical concepts. Students will find it difficult to reason further mathematical concepts when students' basic algebraic arithmetic abilities are weak. This is in line with the National Council of Teachers of Mathematics which states that learning algebra should be aimed at developing students' abilities in (1) understanding patterns, relationships, and functions; (2) representing and analyzing mathematical situations using algebraic symbols and procedures; (3) using mathematical models to express and understand 
quantitative relations; and (4) analyzing the change in various contexts (NCTM, 2010). Apart from NCTM, this is in line with what Drijvers, Goddijn, and Kindt (2010) said, algebraic expertise requires a relationship between basic skills and symbol sense. An element will not form without other elements; for example, students cannot reason algebraically if they cannot perform algebraic operations and vice versa, students often need algebraic reasoning to perform algebraic operations.

There are 3 aspects of algebraic thinking ability, namely generalization, transformational, and global meta-level. According to Kieran, the generational ability is an algebraic ability that includes expressions and equations. Then, transformational abilities are algebraic skills related to rule-based change. Meanwhile, global meta-level abilities are abilities that involve algebra as a good tool in solving algebraic problems and other problems outside algebra (Badawi, Rochmad, \& Agoestanto, 2017). Meanwhile, Foster (2007) emphasizes algebraic thinking in "habits of mind" or thought patterns. One of the important formulations of algebraic thinking is the mindset that students need algebra.

In schools, especially at the junior high school level, students learn a lot about algebra about solving mathematical equations. Solving equations is a key unit in early algebra, and Common Core State Standards Initiative (2010) states that there are two standards. First, it is started from the assumption that the original equation has a solution and each step in solving a simple equation as following from the equality of numbers asserted at the previous step is described afterward. Additionally, a viable argument to justify a solution method is constructed. Second, examples showing how extraneous solutions are provided. With these, the Common Core Standards believes that it is not enough only to solve equations. To perfect it, students must comprehend a deeper the concepts underlying the process of equation solving.

However, many students still have difficulty in mastering the basic skills of algebra. As the results of interviews conducted by Wati and Saragih (2018), they state that algebra lessons are difficult because they contain variables whose values are unknown so that many students are confused when given questions related to algebra. In addition, algebra is a concept that is not easy to learn and teach (Drijvers, Goddijn, \& Kindt, 2010). Solving equations is a pivotal unit in beginning algebra, often confusing and challenging for many students. Many misconceptions prohibiting students 
from developing a deeper understanding of algebra have occurred and persisted since their early learning experiences.

For example, misconceptions surrounding the generalizability of addition or the meaning of the equals sign that may begin in elementary school negatively affect students' understanding of variables and solving equations in beginning algebra classes (Lange, Booth, \& Newton, 2014). Based on the results of an interview with one of the mathematics teachers at EDU Global School, most students are able to understand and solve algebra-based problems if the types of questions are given and are presented with concrete and interesting pictures. However, when given questions in a more abstract book, they still have difficulty solving existing problems or problems. Many students have difficulty learning algebra so they have low algebraic expertise. Difficulty in learning also depends on students' interest in learning.

Interest is a situation where someone desires to know and study and prove more about a certain object with the understanding that there is a more active relationship to that object. According to Nisa (2015) interest is an accidental concentration of attention born willing and dependent on talents and the environment. Furthermore, Hurlock in Kambuaya (2015) states that interest is the result of experience or the learning process. Katz, Assor, KanatMaymon, \& Bereby-Meyer (2006) call interest intrinsic or intrinsic value defined as "the enjoyment people experience when doing a task, or their subjective interest in the content of the task". Meanwhile, according to (Slameto, 2003) developing an interest in something helps students see how the relationship between the material they are expected to study with themselves as individuals. This process means showing students how certain knowledge or skills affect him, but rather his goals, satisfying his needs. If students realize that learning is a tool to achieve several goals that they consider important and if students see that the results of their learning experiences will bring progress to themselves, they will likely be interested (will be motivated) to learn them (Slameto, 2003). So, it is very important for us to know the interest in students' learning in every development of the learning system, especially in the current era, namely digital-based learning.

Martin, Hoskins, Brooks, and Bennett (2013) state that it is very important to choose the right technology to teach materials. However, media and technology must be selected based on various criteria such as learning outcomes, learning strategies, students' characteristics, and learning settings. In other words, the reason for choosing them is not only from their 
availability. Loyola (2016) also states that there are many positive sides to choosing the right media and technology, for example, more effective student learning acquisition, more active student participation in class, and better student understanding of subject matter.

Nowadays, there are changes in social life in society, where social media is the main source of information. Social media is a forum for learning activities, but there are still many educators who are still not open minded about social media as a source of learning due to the inadequacy of technological abilities. Many teachers remain uncertain about meaningfully integrating this technology or assessing its impacts (Crook, 2012). The existence of the covid 19 outbreak has contributed very much to learning activities. Educators inevitably have to adapt and quickly adapt to technology. So, in the new normal era due to the covid 19 outbreak, educators have started to appear to use their social media as a place to learn and share information about learning content. Leveraging social networking capabilities may give teachers and students access to a different culture that helps them clarify their beliefs about teaching with technology and revise their behaviors (Greenhow, 2006). Furthermore, Lederer (2012) points out that social media also plays a role as an educational tool in enriching the learning experience through more attractive connectivity between teachers and students. He underlines that websites such as Social Media-based Mathematics Development and Use, such as Facebook, Twitter, and LinkedIn, are useful for users to dialogue, exchange ideas, and find answers to questions. These sites are designed to enable collaboration and discussion. Also, Lederer states that social media is very useful when used as a learning medium. One of its main benefits is that it can enrich the learning experience by encouraging collaboration and discussion, creating meaningful dialogue, exchanging ideas, and increasing student interaction.

The current phenomenon is that there are often illustrated pictorial puzzle problems related to algebraic calculation operations that are widely uploaded by social media. Social media usually uploads questions on Facebook, Instagram, WhatsApp, Twitter, and so on. The phrase "social networking sites" is an umbrella term used for social media and includes but is not limited to Facebook, Twitter, Linked-in, Myspace. Social Media is internet-based technologies that allow more free-flowing communication among its users (Devi, Eragamreddy, \& Lakshmi, 2019). The relationship between Facebook and well-being appears to become positive over the college 
years, possibly because upper-class students use Facebook to connect socially with their peers and participate in college life (Kalpidou, Costin, \& Morris 2010).

Millennials spend most of their time on gadgets, therefore learning through social media will have a considerable influence on the learning process. Learning algebra with illustrated pictorial puzzles can be packaged in a more interesting and fun way, and students' algebraic thinking ability can be known actively on social media. This is in line with Gnadig's statement which states that puzzles must involve emotions, creativity, and sophistication of students in order to be attractive, paradoxical, and sophisticated. With this, students' curiosity and conceptual understanding can increase. In addition, critical thinking skills, problem strategies, and 'outer box' lateral thinking can be improved (Gnadig, Honyek, \& Riley 2001). Based on the description above, the researcher is eager to investigate how the algebraic thinking ability and learning interest of junior high school students through pictorial puzzles are based on social media in a new normal era. The new normal era requires us to do distance learning so that technology-based learning is needed in this era. Therefore, social media-based pictorial puzzle can be student learning medium to build algebraic thinking.

\section{METHODS}

This type of research is field research, namely direct observation of the object under study in order to obtain relevant data. The method used in this research is descriptive quantitative methods, namely using data analysis techniques in numbers. The stages of the research procedure were (1) literature study, (2) creating an algebraic pictorial puzzle instrument based on social media, (3) test validation by experts, (4) field testing of instruments (5) revision of instruments, (6) sampling, (5) data analysis, and (6) conclusion drawing. The subjects of this study were the 8th-grade students of Edu Global School. There are 6 subjects of this research. The variables observed in this study were students' algebraic thinking skills and students' learning interest in learning pictorial puzzles based on social media. Researchers made tests and questionnaires to determine algebraic thinking ability and student interest in learning. The results were analyzed descriptively. In this study, data collection techniques will be used, namely the test sheet and questionnaire. The questionnaire was based on algebraic thinking ability indicators, namely generalization, transformational, and meta-global levels. Then, student interest 
in learning indicators is desire, feelings of pleasure, knowledge, habits, and attention. Here are some examples of illustrated pictorial puzzle questions based on social media.

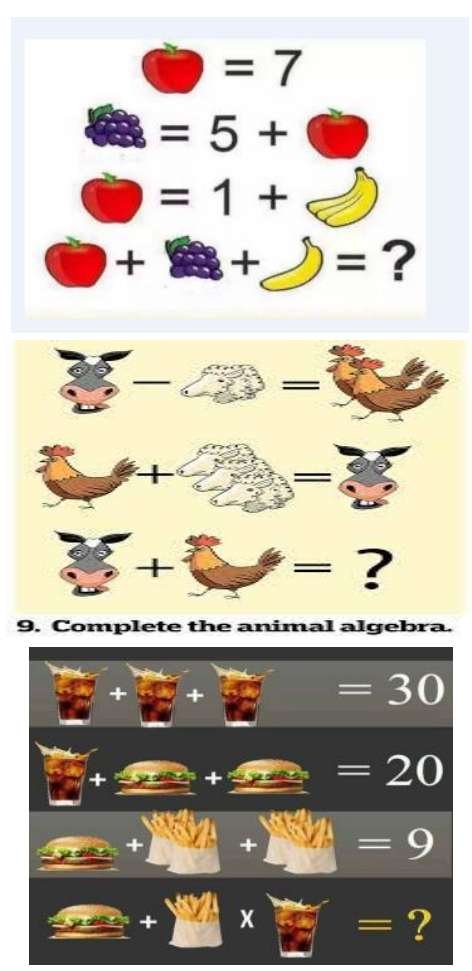

Figure 1. Cartoon Pictorial Puzzle

Researchers conducted a field sample trial of the validity and reliability of tests and questionnaires with a sample of grade 10 at SMAN 1 Beber Cirebon district with as many as 15 students. Then, researchers used the SPSS 20 software program to calculate validity and reliability. The results of tests and questionnaires that have been tested for validity are based on their validity and reliability as instruments that can be used to measure algebraic abilities and students' interest in learning algebra in junior high school.

\section{RESULTS AND DISCUSSION}

1. Results of Data Analysis of Algebraic Thinking Ability

The results of descriptive statistics tests of algebraic thinking ability from the data that have been obtained at the EDU Global School are as follows. 
Table 1. Descriptive Statistics Algebraic Thinking Ability

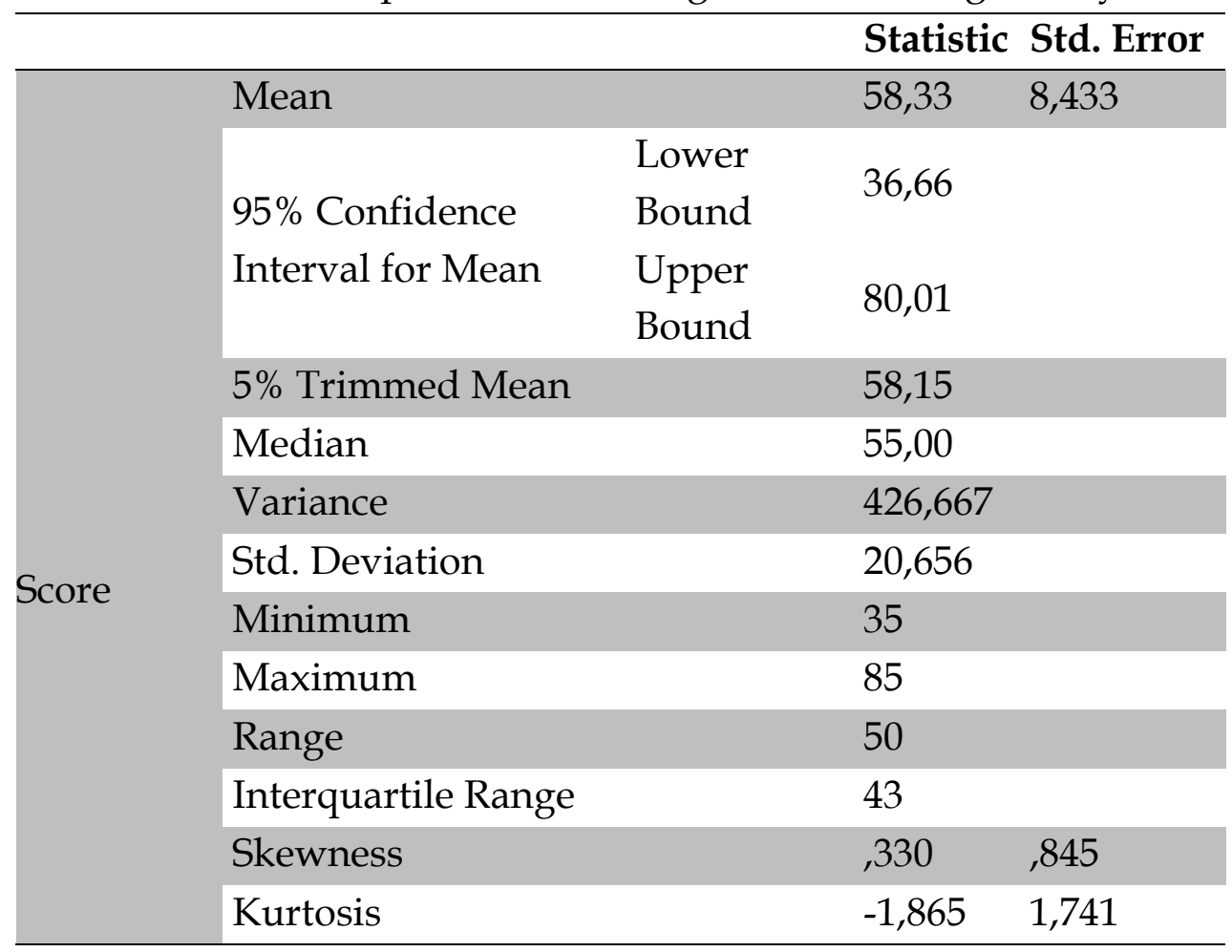

The data obtained from the scoring of algebraic thinking ability was then analyzed to determine students' algebraic thinking ability. The analysis was carried out with the help of Microsoft Office Excel 2010. The steps are as follows.

a. Make a score table for the results of the algebraic thinking ability scale of junior high school students who have received algebraic material.

b. Calculate the algebraic thinking ability scale score of junior high school students with Microsoft Office Excel 2010. The results of the algebraic thinking ability test were assessed using a scoring rubric that had been made.

c. The data results in the form of interval data are then added up to get a total score. After that, it is converted into a percentage with the formula:

$$
\frac{X t o t}{X i} \times 100
$$

In determining the trend of variables, categorization is carried out based on the Mean Ideal and Standard Deviation Ideal according to Mardapi (Desiverlina, 2015), which is obtained by the formula: 


$$
\begin{gathered}
\text { Mean Ideal }\left(M_{i}\right)=\frac{1}{2} x(\text { Xhigh }+ \text { Xlow }) \\
\text { Standart Deviation Ideal }\left(S D_{i}\right)=\frac{1}{6} x(\text { Xhigh }- \text { Xlow })
\end{gathered}
$$

The level of tendency of the variables is categorized into three types with the following categories:

$$
\begin{array}{ll}
x \geq\left(M_{i}+S D_{i}\right) & : \text { High } \\
\left(M_{i}+S D_{i}\right)>x \geq\left(M_{i}-S D_{i}\right) & : \text { Moderate } \\
x<\left(M_{i}-S D_{i}\right) & : \text { Low }
\end{array}
$$

Based on the results of the research data, the scale of the ability to think algebra for junior high school students at Edu Global School is as follows:

Table 2. Recapitulation of Algebraic Thinking Ability Scores

\begin{tabular}{cccr}
\hline Score & Category & Frequency & \multicolumn{1}{c}{$\%$} \\
\hline$x<51.67$ & Low & 1 & $16.7 \%$ \\
$51.67 \leq x<68.3$ & Moderate & 3 & $50 \%$ \\
$x \geq 68.3$ & High & 2 & $33.3 \%$ \\
\hline
\end{tabular}

Based on the results of the above explanation, it can be seen that the algebraic thinking ability of junior high school students are still classified as moderate, and after being analyzed one by one from the results of the existing answers, the majority of them still lack at the global meta-level stage. It can be a task for mathematics educators to continue to look for ways to improve the algebraic thinking ability, which is based on other mathematical thinking ability.

2. Results of Data Analysis of Interest in Learning Algebra

Based on the results of the data obtained from the questionnaire made, the following is the result of descriptive statistics of students' interest in learning algebra through pictorial puzzle questions. 
Table 3. Descriptive Statistics of Interest in Learning Algebra

\begin{tabular}{|c|c|c|c|c|}
\hline & & & Statistic & Std. Error \\
\hline \multirow{15}{*}{$\begin{array}{l}\text { Interest } \\
\text { Score }\end{array}$} & Mean & & 68,67 & 5,090 \\
\hline & & Lower & \multirow{2}{*}{55,58} & \\
\hline & Confidence & Bound & & \\
\hline & Interval for Mean & Upper & \multirow{2}{*}{81,75} & \\
\hline & & Bound & & \\
\hline & \multicolumn{2}{|l|}{ 5\% Trimmed Mean } & 68,57 & \\
\hline & \multicolumn{2}{|l|}{ Median } & 65,00 & \\
\hline & \multicolumn{2}{|l|}{ Variance } & 155,467 & \\
\hline & \multicolumn{2}{|l|}{ Std. Deviation } & 12,469 & \\
\hline & \multicolumn{2}{|l|}{ Minimum } & 55 & \\
\hline & \multicolumn{2}{|l|}{ Maximum } & 84 & \\
\hline & \multicolumn{2}{|l|}{ Range } & 29 & \\
\hline & \multicolumn{2}{|l|}{ Interquartile Range } & 26 & \\
\hline & \multicolumn{2}{|l|}{ Skewness } &, 566 & ,845 \\
\hline & \multicolumn{2}{|l|}{ Kurtosis } & $-1,774$ & 1,741 \\
\hline
\end{tabular}

The results of the recapitulation scale of the students' interest in learning algebra at the EDU Global School are as follows:

Table 4. Recapitulation of Student's Algebra Learning Interest Scale

\begin{tabular}{cccc}
\hline Score & Category & Frequency & $\%$ \\
\hline$x<64.67$ & Low & 2 & $33.3 \%$ \\
$64.67 \leq x<74.3$ & Moderate & 2 & $33.3 \%$ \\
$x \geq 74.3$ & High & 2 & $33.3 \%$ \\
\hline
\end{tabular}

Based on the results obtained, it can be seen that students' interest in learning algebra is still evenly distributed, some like learning algebra, some are just doing it, and some are still less interested in learning algebra through these pictorial puzzle questions. This can be used as further research material for learning mathematics using pictorial puzzle questions found on social media to build algebraic thinking ability.

This shows that social media can be used to measure mathematics skills and can even be used as a learning medium. Oye, Abrahim, and Holeu (2012) for example, through their research entitled "The Effect of Social Networking Sites on Student Academic Performance", find that many of the respondents 
agree that social networking sites help their academic work. In addition, $\mathrm{Ng}$ and Latif (2013); Naganjaneyulu and Prasad (2013) conduct research on social media and mathematics learning to enhance mathematics learning, and their research concludes that social media enhances students' learning and teaching experiences.

However, because the achievement of the results of algebraic thinking skills and students' interest in learning algebra has not been maximal, teachers must find various ways and strategies that are more effective to understand and are motivated in learning algebra. Various ways can be done based on the recommendations of Jon Star's statement, namely:

Recommendation 1. Use solved problems to engage students in analyzing algebraic reasoning and strategies.

a. Have students discuss solved problem structures and solutions to make connections among strategies and reasoning.

b. Select solved problems that reflect the lesson's instructional aim, including problems that illustrate common errors.

c. Use whole-class discussions, small-group work, and independent practice activities to introduce, elaborate on, and practice working with solved problems.

Recommendation 2. Teach students to utilize the structure of algebraic representations.

a. Promote the use of language that reflects mathematical structure.

b. Encourage students to use reflective questioning to notice structure as they solve problems.

c. Teach students that different algebraic representations can convey different information about an algebra problem

Recommendation 3. Teach students to choose from alternative algebraic strategies when solving problems intentionally.

a. Teach students to recognize and generate strategies for solving problems.

b. Encourage students to articulate the reasoning behind their choice of strategy and their strategy's mathematical validity when solving problems.

c. Have students evaluate and compare different strategies for solving problems. (Star, Foegen, Larson, McCallum, Porath, Zbiek, \& Windsor, 2015).

Student rejection of the new strategies the teacher uses is natural. This is no different from students who have completed units that combine the worked example problems. Lange, Booth, and Newton (2014), through their research, 
also found that students were initially surprised by the new approach but later felt that they were learning more.

\section{CONCLUSION}

The algebraic thinking ability of students at SMP Edu-Global School is still in the moderate category. There is also an interest in learning algebra for students at SMP Edu-Global School, which is moderate. The algebraic thinking ability and algebraic interests of students at SMP Edu-Global School need to be improved more to achieve algebraic thinking ability and students' interest in learning at the high category level. This is the teacher's task or further researcher to find ways to improve algebraic thinking ability and student interest in learning, either by exposing algebraic material or learning methods to be applied.

\section{ACKNOWLEDGMENT}

The author would like to thank the Ministry of Research, Technology, and Higher Education who has funded this research in the Beginner Lecturer Research (PDP) scheme.

\section{REFERENCES}

Angriani. (2017). Kemampuan Berpikir Aljabar dan Self-Efficay Matematis Siswa SMP melalui Pendekatan Concrete Pictorial-Abstract (CPA). Pacasarjana UPI: Tidak diterbitkan.

Badawi, A., Rochmad, \& Agoestanto, A. (2017). Analisis Kemampuan Berpikir Aljabar dalam Matematika pada Siswa SMP Kelas VIII. Unnes Journal of Mathematics Education, 5(3), 76-83. https://doi.org/10.15294/ujme.v5i3. 13100.

BSNP. (2006). Panduan Penyusunan Kurikulum Tingkat Satuan Pendidikan Jenjang Pendidikan Dasar dan Menengah. Badan Standar Nasional Pendidikan.

Common Core State Standards Initiative (CCSSI). (2010). Common Core State Standards for Mathematics. Washington, DC. National Governors Association Center for Best Practices and the Council of Chief State School Officers.

Crook, C. (2012). The 'digital native' in context: tensions associated with importing Web 2.0 practices into the school setting. Oxford Review of Education, 38(1), 63-80. https:/ / doi.org/10.1080/03054985.2011.577946.

Devi, K., Eragamreddy, G., \& Lakshmi V, V. (2019). Role of Social Media in Teaching-Learning Process. Journal of Emerging Technologies and Innovative Research, 6(1), 96-103. Retrieved from https://www. 
researchgate.net/publication/330497773_Role_of_Social_Media_in_Tea ching-Learning_Process.

Drijvers, P., Goddijn, A., \& Kindt, M. (2010). Algebra Education: Exploring Topics and Themes BT - Secondary Algebra Education: Revisiting Topics and Themes and Exploring the Unknown (P. Drijvers (ed.); pp. 5-26. SensePublishers. https:// doi.org/10.1007/978-94-6091-334-1_1.

Foster, D. (2007). Making Meaning in Algebra: Examining Students' Understandings and Misconceptions. In A. H. Schoenfeld (Ed.), Assessing Mathematical Proficiency (pp. 163-176). Cambridge University Press. https://doi.org/ 10.1017/CBO9780511755378.017.

Gnadig, P., Honyek, G., \& Riley, K. (2001). Puzzling physics problems, with hints and solutions. Cambridge(UK). UK: Cambridge University Press.

Greenhow, C. (2006). From blackboard to browser: An examination of teachers' constructivist beliefs and practice in using the internet. USA: Harvard University.

Kalpidou, M., Costin, D., \& Morris, J. (2010). The Relationship Between Facebook and the Well-Being of Undergraduate College Students. Cyberpsychology, Behavior and Social Networking, 14(4), 183-189. https:// doi.org/10.1089/cyber.2010.0061.

Kambuaya, C. (2015). Pengaruh motivasi, minat, kedisiplinan dan adaptasi diri terhadap prestasi belajar siswa peserta program afirmasi pendidikan menengah asal Papua dan Papua Barat di Kota Bandung. Share Social Work Journal, 5(2), 157-166. https:/ / doi.org/10.24198/share.v5i2.13140.

Katz, I., Assor, A., Kanat-Maymon, Y., \& Bereby-Meyer, Y. (2006). Interest as a Motivational Resource: Feedback and Gender Matter, but Interest Makes the Difference. Social Psychology of Education, 9(27), 27-42. https:// doi.org/10.1007/s11218-005-2863-7.

Lange, K., Booth, J. L., \& Newton, K. J. (2014). LearNiNG aLGeBra FrOM. 107(7).

Lederer, K. (2012). Pros and Cons of Social Media in the Classroom, Campus Technolog. Campus Technology.

Loyola, C. (2016). Teaching-learning Process: Instructional Media and Technology, Dale's Cone of Experience.

Maftoon, P., \& Sarem, S. (2012). The Realization of Gardner's Multiple Intelligences (MI) Theory in Second Language Acquisition (SLA). Journal of Language Teaching and Research, 3(12), 33-41. https:/ / doi.org/ 10.4304/jltr.3.6.1233-1241.

Martin, F., Hoskins, O., Brooks, R., \& Bennett, T. (2013). Development of an Interactive Multimedia Instructional Module. Journal of Applied Instructional Design, 3(3), 5-17. Retrieved from https://www. researchgate.net/publication/272151941_Development_of_an_Interacti ve_Multimedia_Instructional_Module.

Naganjaneyulu, V., \& Prasad, A. R. (2013). Mathematics Teaching, Learning 
and Assessment using Latest ICT tend Social Media. Asian Technology Conference in Mathematics. Thailand.

NCTM. (2000). Six Principles for School Mathematics. Reston, VA: NCTM.

$\mathrm{Ng}$, R., \& Latif, L. (2013). Social Media and the Teaching of Mathematics in a Lifelong Learning Environment. Journal of Chemical Information and Modeling, 53(9), 1689-1699.

Nisa, A. (2015). Pengaruh perhatian orang tua dan minat belajar siswa terhadap prestasi belajar ilmu pengetahuan sosial. Faktor: Jurnal Ilmiah Kependidikan, 2(1), 1-9. https://dx.doi.org/10.30998/.v2i1.370.

Oye, N., Rahim, Z. Z., \& Helou, A. M. (2012). Students' perceptions on social networking sites influence on academic performance. Journal of Social Networking and Virtual Communities, 1. https://doi.org/10.11591/ socnetvircom.v1i1.540.

Putri, D. K., Sulianto, J., \& Azizah, M. (2019). Kemampuan Penalaran Matematis Ditijau dari Kemampuan Pemecahan Masalah. International Journal of Elementary Education, 3(3), 351-357. https:// http:// dx.doi.org/10.23887/ijee.v3i3.19497.

Slameto. (2003). Belajar dan Faktor-faktor yang Mempengaruhinya. Rineka Cipta.

Star, J. R., Foegen, A., Larson, M. R., McCallum, W. G., Porath, J., Zbiek, R. M., Windsor, W. (2015). Motivational Strategies in the Teaching of Primary School. Anales de Psicologia, 2(2), 369-376.

Wanti, N., Juariah, J., Farlina, E., Kariadinata, R., \& Sugilar, H. (2017). Pembelajaran Induktif pada Kemampuan Penalara Matematis dan SelfRegulated Learning Siswa. Jurnal Analisa, 3(1), 56-69. https://doi.org/ 10.15575/ja.v3i1.1497.

Wati, E., \& Saragih, M. (2018). Difficulties in Learning Mathematics Concepts in Algebra: A Case Study of Grade VII Students in ABC School Lampung. Polyglot: Jurnal Ilmiah, 14(1), 53. https://doi.org/10.19166/ pji.v14i1.453. 